University of Nebraska - Lincoln

DigitalCommons@University of Nebraska - Lincoln

H. W. Manter Laboratory Library Materials

9-1919

\title{
On the Specific Identity of Heronimus chelydrae MacCallum and Aorchis extensus Barker and Parsons
}

Horace Wesley Stunkard

New York University

Follow this and additional works at: https://digitalcommons.unl.edu/manterlibrary

Part of the Parasitology Commons

Stunkard, Horace Wesley, "On the Specific Identity of Heronimus chelydrae MacCallum and Aorchis extensus Barker and Parsons" (1919). H. W. Manter Laboratory Library Materials. 23.

https://digitalcommons.unl.edu/manterlibrary/23

This Article is brought to you for free and open access by DigitalCommons@University of Nebraska - Lincoln. It has been accepted for inclusion in H. W. Manter Laboratory Library Materials by an authorized administrator of DigitalCommons@University of Nebraska - Lincoln. 


\section{ON THE SPECIFIC IDENTITY OF HERONIMUS CHELYDRAE MACCALLUM AND AORCHIS EXTENSUS BARKER AND PARSONS}

\section{Horace W. Stunkard}

The monostomes are among the least known of North American trematode groups. Records give descriptions of only six species, each the single representative of a genus, and according to the classification of Ward (1918) belonging to four different families. Existing descriptions in most cases are far from complete and data necessary for taxonomic determination are lacking. This deficiency has been pointed out by other workers, both in this country and in Europe, and the classification of the monostomes is not well established. In fact, certain investigators regard them as aberrant forms, sprung from different distome groups, which alike have lost the acetabulum. If this is true and the similarity is merely superficial, the present system of classification must be entirely revised. Careful, complete descriptions of these forms are necessary to provide the data for a natural system of classification. The present study, it is hoped, will prove a step toward the solution of this problem:

Heronimus chelydrae was described by MacCallum (1902) from the lungs of the American snapping turtle, Chelydra serpentina, taken at Ontario, Canada. After the description of the form, the author stated, "It seems necessary, therefore, to establish a new genus in the family Monostomidae to accommodate this form-a genus which stands far apart from the other genera in several respects, but especially in the position and nature of the genital opening, in the complicated structure and course of the uterine tract, the unusual formation of the yolk glands, in the presence of but one testicle, and in the position of the excretory pore."

Barker and Parsons (1914) in a preliminary announcement described a monostome, parasitic in the lungs of Chrysemys marginata, which they named Aorchis extensus. In a later paper (Barker and Parsons, 1917) they gave a more extended description of the form based on the study of the specimens originally secured from Lake Emily, Minnesota, and others found later in the lungs of the same host taken from the Mississippi River near Fairport, Iowa. As diagnostic characters of the genus Aorchis they stated:

"Body medium to large, slightly tapering toward the anterior and posterior ends, posterior end rounded. Oral sucker small, weak but distinct. Mouth opening terminal. Pharynx strongly muscular, with- 
out pockets. Esophagus short. Intestine composed of two simple blind sacs, not uniting at the posterior end. Genital pore not prominent, ventral to the pharynx, close to oral sucker. Ovary anterior between intestinal ceca. Shell gland compact, posterior to and smaller than ovary. Uterus made up of coils which fill the body lateral to and overlap the intestinal ceca, extending from level of the ovary to posterior end of the body and two straight and parallel uterine tubes which pass anteriorly up the median axis of the body between the intestinal ceca. Vitelline gland a voluminous, coarse, compact, U-shaped mass posterior to ovary and dorsal to the intestine, with the closed portion at the anterior end. Protandrous. Testis absent, or atrophied in old worms. A single ovoidal testis present in young worms, anterior, caudad to ovary. Prostate gland near testis, seminal vesicle, a large tubular structure extending from genital pore to the level of the second anterior fifth of the body. Protrusible nonmuscular cirrus present. Laurer's canal and seminal receptacle absent. Eggs without lids. Excretory pore posterior dorsal."

A new family, Heronimidae, was created by Ward (1917) to contain the two genera Heronimus and Aorchis. This author had collected specimens which he stated probably belonged to the species $A$. extensus, from the lungs of various turtles from Michigan, Indiana, Illinois and Nebraska. Comparing the two genera he says, "These two forms are so much alike that they may prove to be identical, or at least to belong to the same genus, but they are in some respects very different from any other monostomes known, and I have established for them a new family with the following characters:

"Heronimidae Ward. Moderate sized monostomes with thick, elongate, soft body, slightly flattened, tapering toward both ends. Oral sucker weak, pharynx large, esophagus short or absent; ceca simple, narrow, extending to posterior tip but not united. Vitellaria compact tubular; uterus with four longitudinal regions; genital pore ventral to oral sucker, near anterior tip. Testis tubular, small, copulatory apparatus poorly developed. In lungs of turtles, northern North America."

The following year, Ward (1918) restated the family characters with the following additions: "Vitellaria compact tubular, shaped like an inverted V. Testes tubular, lobed or with short branches, united into a V-shaped organ with the apex anteriad. . . . Two genera imperfectly known which may prove to belong in the same genus." The genera Heronimus and Aorchis he distinguished as follows:

"Vitellaria extend only half way from ovary to posterior end. Seminal receptacle present . . Heronimus MacCallum 1902.

"Vitellaria extend from ovary to posterior end of body. Seminal receptacle absent. . . . Aorchis Barker and Parsons 1914." 
Ward (1918) gave two figures of $A$. extensus and a brief specific description. He differed from Barker and Parsons with regard to the testis. Ward found "Testes elongate, tubular, irregularly lobed."

While engaged for several years in the study of animal parasites, I have examined about three hundred turtles and found a large monostome in the lungs of six different species collected from the central and southern as well as northern districts of North America. This parasite has been secured from Chelydra serpentina taken in Iowa, Illinois, Ohio, North Carolina and Texas. Specimens have been found in the lungs of Chrysemys marginata taken in Iowa, Illinois, Missouri and Kentucky; Pseudemys elegans and Malacoclemmys geographicus in Illinois; Aromochcly's odoratus and Kinosternum pennsylvanicum in North Carolina.

This form I had regarded as identical with $A$. extensus Barker and Parsons and the close similarity to $H$. chelydrae had been noted. Through the kindness of the director of the U. S. National Museum, I have had an opportunity recently to study the specimens of Heronimus chelydrae deposited there by MacCallum. In addition, a large specimen of $H$. chelydrae from the collection of Albert Hassall has been placed at my disposal. This worm is from the lung of Kinosternum pennsylvanicum taken near Baltimore, Maryland. I wish to express here my thanks to these workers for their kind assistance.

A careful examination of the specimens and comparison with the description of MacCallum confirms his observations. He gave a careful description of the morphology of the parasite and a detailed histological description of certain structures. He described the uterus as extensively convoluted and folded, traversing the length of the body four times, but he did not describe the definite course of the tube and his figure gives a diagrammatic representation rather than a precise picture of the position of the loops and coils of the uterus. Further, he did not describe the extent of the testis or state that in certain specimens this organ is reduced or degenerate.

Comparison of the monostomes I have collected with the type specimen and other sectioned individuals of $H$. chelydrae shows fundamental and precise agreement in every respect and demonstrates that they belong to that species.

A careful study of the material of $H$. chelydrae yields results strikingly different from those of Barker and Parsons. The difference in certain features is so marked that I may be dealing with another species, but in other respects there is such precise agreement that I am inclined to believe $I$ have the same form. Some of the specimens at hand are from the same host and the same locality where Barker and Parsons' material was collected. They agree with the description of Barker and Parsons in size and shape, size and character of the oral 
sucker, pharynx, esophagus and digestive ceca, extent and position of the uterine coils, size and position of the ovary, character of the copulatory organs, and location of the genital pore. But in $H$. chelydrae the excretory system is different from that described by Barker and Parsons, the pore is near the anterior instead of the posterior end of the body, the vitellaria are ventral and not dorsal, a seminal receptacle is present, also a $\mathrm{V}$-shaped testis which corresponds in size and extent with Barker and Parsons' description of the vitellaria. If these differences were minor in character, I should conclude that the specimens belong to a different species, but the form of the excretory system is a fundamental and characteristic feature of large groups, and questions that involve the dorso-ventral axis or concern the form of the testis and vitellaria are not of specific nature. Consequently, in view of the agreement in other respects, I am inclined to question the accuracy of Barker and Parsons' description. In their first report (Barker and Parsons, 1914) the eggs are described as possessing a short polar stalk and a statement is made that the cirrus is lacking. Their later paper (1917) does not refer to any polar stalk on the eggs and a cirrus is described. Ward (1918) has made further corrections to the description. The comparison of $H$. chelydrae with the description of Aorchis extensus leaves little if any doubt that the two forms are identical. Barker and Parsons do not refer to the work of MacCallum and have not published a comparison of their form with $H$. chelydrae. The unsatisfactory nature of Barker and Parsons' description and the agreement of the parasites described by them with Heronimus chelydrae discredits the validity of the genus Aorchis and the name should be suppressed.

Supplementing the work of MacCallum, I wish to make certain additions to the description of Heronimus chelydrae. In the examination of turtles, the heaviest infection found was six flukes in one host, and though the parasite is not uncommon, the relative infection was slight. On the findings in three male and two female turtles, Barker and Parsons. endeavor to show the females more heavily infected than the males. Such a conclusion seems unfounded, and in the examination of over fifty infected turtles, I find practically no difference as far as sex of host is concerned.

The body of the living worm is usually curved and often assumes the form of a double bend like an elongated $\mathrm{S}$, the short anterior region becomes concave ventrally and the long posterior part concave dorsally. Movement is slow and sluggish. The size and shape of the parasite have been described by both MacCallum and Barker and Parsons. Apparently the measurements of both were made from fixed specimens, and this can account for the slight difference in their reports. I have observed specimens that measured $18 \mathrm{~mm}$. when fully extended that 
did not exceed $12 \mathrm{~mm}$. in the normal characteristic form. The relative width naturally varies with the amount of elongation. MacCallum described the cuticula as sometimes thrown into slight folds or rugae independent of the musculature. Barker and Parsons described strong circular bands of muscle fibers which run around the body at regular intervals and give it a segmented appearance when contracted. I have observed the same conditions, the slight folding of the cuticular covering and also the more pronounced constrictions involving the muscular wall. But in sections I have been unable to demonstrate any regularly occurring bands of strong circular muscle fibers or even an intermittent thickening of the circular muscles of the body wall. The musculature is very weak and slight, no one of the three layers which form the body wall is strongly developed. Lying inside the body wall there is a compact layer of parenchyma (Figs. 3, 5, 6, 9), and this layer increases in thickness anterior to the ovary. Within the outer thickened stratum the parenchyma has the loose vacuolated appearance (Figs. 3,9) well described by MacCallum.

The measurements of the oral sucker, pharynx, esophagus and intestinal ceca agree with those given by Barker and Parsons, and my examination confirms the histological description of these structures as given by MacCallum.

MacCallum described the ovary as located on the left side of the body. Barker and Parsons' statement concerning the size and position of the ovary agrees with that of MacCallum except that they found the ovary on either the right or left side. My observations confirm the statement of Barker and Parsons; the ovary may be on either the left or right side, but is always on the side opposite from the anterior pigmented region of the uterus. The description of the structures which comprise the oötype as given by MacCallum is entirely confirmed by my observation. A seminal receptacle is present (Fig. 3). It is about one fourth the size of the ovary, situated on the postero-median side of the ovary. It agrees in size and position with Barker and Parsons' description of the testis. In the specimens in which I have been able to trace the course of the uterus, it passes from the oötype to the side of the body opposite from the ovary and posteriad in many coils around the intestine and testis to the posterior end of the body. Then it bends forward and continues anteriad on the ovarian side in similar coils and loops to the level of the ovary, where it turns posteriad and passes diagonally to the opposite side of the body. Here it turns anteriad and soon becomes heavily pigmented. It extends in many loops and folds to or slightly farther than the level of the ovary and then turns caudad, extending as a straight tube in the dorso-median line almost to the posterior end of the body. The pigmentation diminishes as the tube passes caudad and in many specimens disappears about 
midway between the ovary and the posterior end of the body. At its posterior end, the descending median section of the uterus turns ventrad and opens into the large, median, ventral sac-like portion (Fig. 7) which extends cephalad to the metraterm. The histological character of the various regions of the uterus has been described by MacCallum and the character of the copulatory organs and position of the genital pore by both MacCallum and Barker and Parsons.

The vitellaria (Figs. 7, 10,11) consist of two glandular structures which meet anteriorly to form the vitelline receptacle and extend almost to the posterior end of the body. They lie median and ventral to the ceca, the anterior part is tubular, but the central and posterior regions are solid and rodlike.

The eggs are very thin-shelled and, when massed together in the uterus, lose their characteristic shape and become many-sided. Often the shells are lost entirely, the embryos develop eye spots, and in the large sac-like terminal portion of the uterus, there are fully developed ciliated miracidia. This species offers, then, an opportunity to follow the development of the embryo from the maturation and fertilization of the egg to the first larval stage.

The testis (Figs. 7, 8, 10,11) is a large U- or V-shaped structure; the closed portion is cephalad and situated one fourth to one fifth of the body length from the anterior end. The crura extend caudad to a level about one eighth of the body length from the posterior end. As described by Ward, they are elongate, tubular, irregularly lobed. Their histological appearance is well described by MacCallum and is shown in Figs. 7, 8, 11. Barker and Parsons described a condition in which the testis is atrophied and degenerate, and stated that this is true particularly in the "older larger worms." I have observed the same condition in many individuals of $H$. chelydrae. Often, however, the organ is degenerate and the crura of the testis have shrunk to mere strands of tissue, and sections show the cells in a state of degeneration and disintegration. On the other hand, however, in many of the largest individuals the testis is full-sized and sections show vigorous functional activity of the cells. I am at a loss to account for the atrophy of the testis, but since it occurs in a large percentage of small individuals, and does not occur in many of the largest, I am not inclined to regard the conclusion of Barker and Parsons as satisfactory.

A short vas deferens arises from the anterior part of the testis, turns ventrad and caudad where it opens into the posterior end of the seminal vesicle. No prostate gland was found. The seminal vesicle extends caudad only a short distance from the median part of the testis and the posterior part of the vesicle is usually irregularly coiled. The vesicle extends anteriad in the ventral part of the body and just anterior to the ovary passes over into the cirrus sac (Fig. 4). This sac is 
approximately the same width as the vesicle and the wall is not strongly muscular. The copulatory structures have been discussed.

The excretory system consists of a large, median, dorsal collecting vesicle and smaller ducts distributed throughout the tissue of the body. The large dorsal collecting vesicle extends from the pharyngeal region almost to the posterior end of the body and opens to the exterior in the median dorsal line just posterior to the pharynx. Its walls are often folded and it lies in loose vacuolated parenchymatous tissue. No definite branches from this vesicle were demonstrated. The two largest excretory ducts (Fig. 6) arise in the region of the oral sucker and pass caudad, one on either side of the body, ventral and median to the ceca. They become smaller and more dorsal in position as they extend posteriad and near the posterior end of the seminal vesicle they disappear in the loose parenchyma.

\section{SUMMARY}

The present study demonstrates the specific identity of Heronimus chelydrae MacCallum and Aorchis extensus Barker and Parsons. It confirms the work of MacCallum and includes many additions to the description of the species. The course of the uterus is traced and the position, extent and atrophy of the testis is demonstrated. The wide distribution of the species, and its infestation of six different species of turtles, are items of interest and importance.

BIBLIOGRAPHY

Barker, F. D., and Parsons, S. 1914.-A New Species of Monostome from the Painted Terrapin, Chrysemy's marginata. Zool. Anz., 45:193-194.

1917.-A Monostome Lung Fluke from the Painted Terrapin, Chrysemys marginata Agassiz. Trans. Amer. Micr. Soc., 36:55-66, 2 pl.

MacCallum, W. G. 1902.-Heronimus chelydrae, nov. gen., nov. sp. A New Monostome Parasite of the American Snapping Turtle. Centr. Bakt. Par., Orig., 32:632-636, 2 figs.

Ward, Henry B. 1917.- On the Structure and Classification of North American Parasitic Worms. Jour. Paras., 4:1-12.

1918.-Parasitic Flatworms, Trematoda. Fresh-Water Biology. Ward and Whipple. 


\section{Explanation of Figures}

(All camera lucida tracings)

1. Type specimen of Heronimus chelydrae, dorsal view, $\times 8$.

2. Ovary and oötype region, from large mounted specimen, $X 25$.

3. Sagittal section showing ovary, seminal receptacle, vitelline receptacle and beginning of uterus, $\times 57$.

4. Sagittal section showing excretory pore, genital pore, extent of cirrus sac, and relation of pharynx and esophagus, $\times 57$.

5. Cross section at posterior end of pharynx, showing nerve commissure and relation of uterus and cirrus sac, $\times 57$.

6. Cross section at level of excretory pore, showing uterus, cirrus sac and small anterior excretory ducts, $\times 57$.

7. Cross section near the posterior end of the body, just -anterior to the point where the median descending section of the uterus opens into the large ventral sac-like portion. The vitellaria and crura of the testis extend posterior to this level and appear in the section, $\times 57$.

8. Sagittal section, lateral to intestine, showing testis and uterine coils, $\times 27$.

9. Cross section thru body at anterior tip of ovary, $\times 48$.

10. Cross section at the level of the oötype, showing anterior tip testis, tubular nature of the anterior part of the vitelline gland, large sac-like nature of the terminal portion of the uterus and the smaller pigmented descending section of the uterus dorsal to it, $\times 42$.

11. Cross section just anterior to the bifurcation of the testis, showing the rod-like character of the vitellaria, $\times 29$.

12. Sagittal section showing oral sucker and pharynx, genital pore, uterus and cirrus sac, $\times 87$.

$\begin{array}{ll} & \text { Abbreviations UsEd IN Figures } \\ c s \text { - cirrus sac } & o s \text { - oral sucker } \\ e d \text { - excretory duct } & p h \text { - pharyix } \\ c v \text { - excretory vesicle } & s v \text { - seminal vesicle } \\ e p \text { - excretory pore } & s r \text { - seminal receptacle } \\ i \text { - intestine } & t \text { - testis } \\ m g \text { - Mehlis' gland } & u \text { - uterus } \\ n c \text { - nerve commissure } & v \text { - vitellaria } \\ o \text { - ovary } & v r \text { - vitelline receptacle } \\ o d-\text { oviduct } & \end{array}$




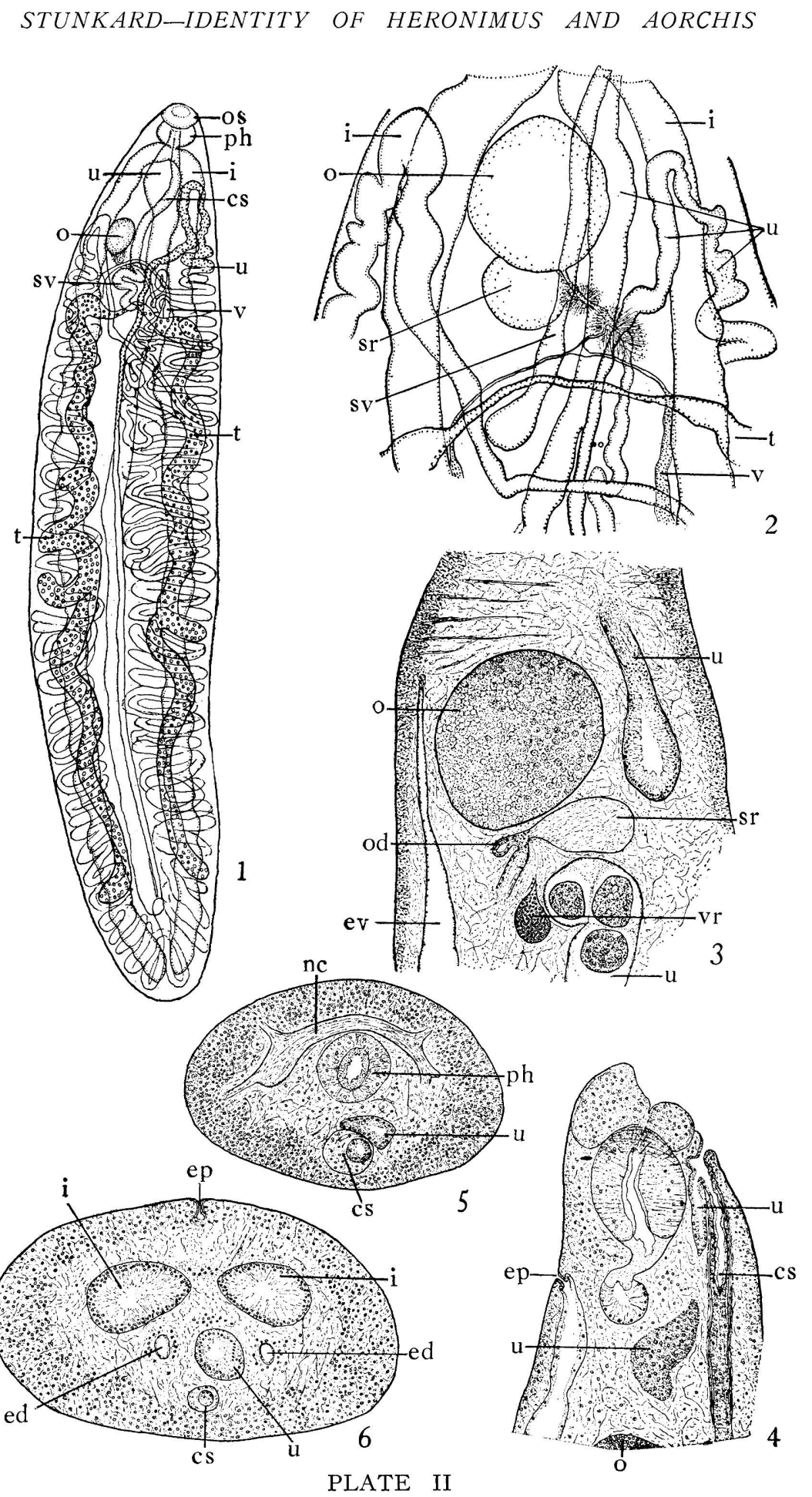


STUNKARD-IDENTITY OF HERONIMUS AND AORCHIS
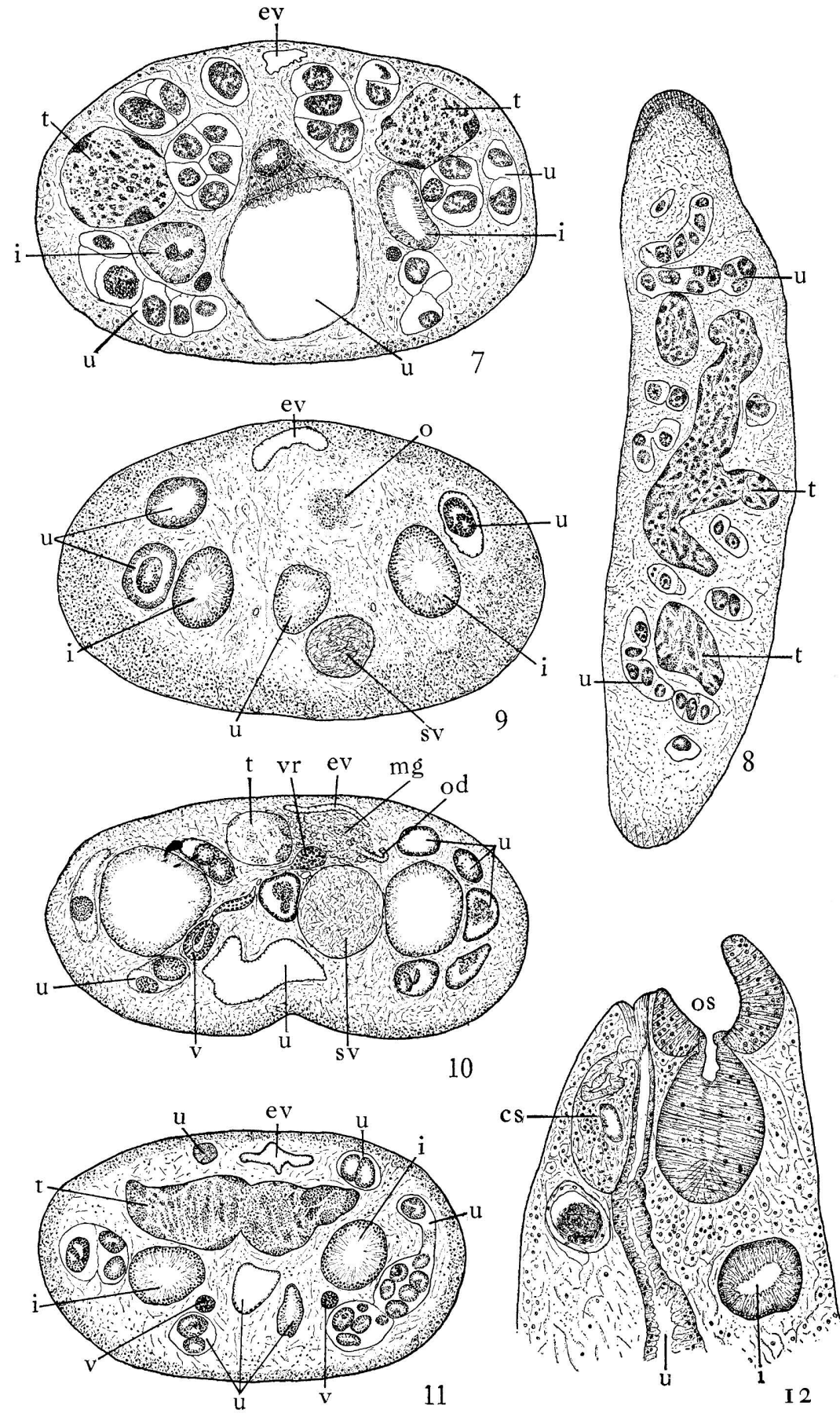

PLATE III 